\title{
Ghosts in the Garden: locative gameplay and historical interpretation from below ${ }^{1}$
}

\author{
Steve Poole \\ University of the West of England, Bristol
}

Over the last decade, digital mobile technologies have played a leading role in transforming the visitor experience at European sites of heritage. ${ }^{2}$ Applications for phone and tablet have allowed heritage site managers greater control over the delivery of interpretative content by triggering automatic audio or visual interventions. Paradoxically, mobile apps have simultaneously permitted visitors an impression of greater agency in environments less cluttered with signage and props, and less reliant on their ability to find the right page in the guidebook. Apps invite forms of content design in which greater degrees of interactivity and even personalisation are privileged. In the educational sector, this potential is slowly gaining recognition and a number of institutions have begun to experiment with locative app design to change the ways students engage with, understand and evaluate primary historical evidence. ${ }^{3}$ However, most critical commentary on these processes has been dominated to date by reflections on form rather than content and purpose, and little in the way of systematic analysis of locative experiential interpretation at historic sites using mobile devices has been attempted. ${ }^{4}$ The question we should in any case be asking perhaps, is not "how can we use mobile and digital technologies to get larger and more diverse audiences through the door?', but 'how can we use mobile and digitally enhanced forms of interpretation to change the questions we ask and the ways in which we engage with historic sites?'

There are, broadly, three main ways in which digital technologies, some mobile and some static, have been considered for use in the heritage environment: as an augmented guidebook and information resource, as a tool for enhanced simulation, and (less frequently) as a tool for changing the rules by which we construct and define historical knowledge at heritage sites. This essay reviews each of these approaches in turn and argues the case for a deeper engagement with the third. Locative mobile technologies, it is suggested, have the potential to positively transform some of the ways in which visitors to heritage sites are addressed, challenging the notion that historical data is best presented for passive consumption, and promoting, as an alternative, an experiential model of knowledge built upon agency, dialogue and informed choice. Ghosts in the Garden, an experimental project in which the author was a researcher and participant, is presented here as a case study. Its rationale was to disrupt both the form and the content of traditional interpretative approaches to the use of mobile, firstly by concealing the technology, secondly by requiring collective evaluation and decision making, and thirdly by commissioning original historical content 'from below'.

\section{Downloadable tour apps}

In the first approach considered here, phone and tablet apps, freely downloadable from the Apple IStore and Google Play, dominate the field, and companies like Audio Tours, Treasure Trails and ATS Heritage ('Creating remarkable visitor experiences across the cultural sector'), offering cheaply produced, off the peg, modular guides to the heritage attractions of British urban centres, have emerged as market leaders. Typically, apps of this kind use locative GPS software and a simple mapping system to guide users around a town's historic sites, alerting them on arrival at each with 
contextual photographs or other contemporary illustrations, graphic reconstructions, and short snippets of 'factual' information in text and/or audio format. The marketplace is an extremely competitive one, where tight budgets prompt 'value for money' offers from producers. Audio Tours' 'Welcome To...' platform, adaptable from a basic format to any site and with a choice of 'add-ons', had a starting price of $£ 2,500$ in January 2016. Calvium, a Bristol-based start-up was synonymously exploring the potential for a simple framework app that allows small heritage sites to upload content for as little as $£ 500$ per app. ${ }^{5} \mathrm{~A}$ growing number offer an 'armchair' mode, enabling content to be explored off-site and without the need for GPS triggering. ATS Heritage, whose rosta of clients includes Highclere Castle, Uppark House and the Royal College of Physicians, summarise the attraction of armchair mode quite simply: 'With high numbers of smartphone users, visitor apps are a golden opportunity to extend your marketing reach... and engage with visitors before they're even on site'. ${ }^{6}$

Academic historical input is rare in the development of apps like these; they tend to make use of previously published historical knowledge and materials rather than commission new research, and are frequently put together by local authorities and community organisations whose objectives favour economic regeneration and social cohesion over complex interpretations of the past. Dissonant histories are unlikely to be revealed. In 1977, for example, an area of former industrial land beside the Leeds and Liverpool Canal in Burnley was renamed 'The Weavers' Triangle' by the town's Industrial Museum Action Committee and work was begun to promote 'the preservation of the town's heritage'. A downloadable phone app was then commissioned from Treasure Trails by Mid Pennine Arts to guide visitors around the area's industrial remains. Promotional material makes the agenda and purpose clear and engagement with difficult histories is not a priority: 'This area is currently the focus of a major regeneration programme being undertaken by Burnley Borough Council, which aims to capitalise on the distinctive heritage of the area in order to strengthen the local economy and boost tourism', it declares, and the subtitle is 'Project Pride Burnley'. ${ }^{7}$

\section{Enhanced and affective simulation}

In the second approach, developments in surround-sound, 360 degree film or augmented and virtual reality ( $A R$ and VR) have enabled enhanced forms of visual and audio reconstruction, particularly at archaeological sites, and in any historic landscape in which either material remains have not survived, or the desire for an experiential relationship with an historic event prompts virtual reconstruction. Here, digitally enhanced video event reconstruction has become steadily more immersive in its pursuit of 'the real'. The National Trust for Scotland's 2002 'immersion theatre' at the Culloden battlefield, Inverness, which places visitors at the centre of the conflict by playing film onto four surrounding screens, was still rated the most popular feature in the visitor centre in 2011. Nevertheless, it is considerably less advanced than the Trust's 2014 motion capture video 'Battle Room' at Bannockburn which uses 'cutting edge 3D technology' that allows visitors to 'witness the sights and sounds of battle as it would have been in 1314', and where 'by means of digital enhancements, the swords and lances are shown striking and penetrating armour and flesh'. Developed in partnership with design consultants, Bright White, and Glasgow School of Art's Centre for Digital Documentation, the Bannockburn Battlefield Experience has been showered with industry awards and now promotes itself as 'the first heritage centre in the world using Hollywood-calibre motion capture to immerse visitors in a realistic and historically accurate 3D medieval battle'. Importantly, although visitors are 'strongly encouraged' to sample the delights of experiential immersion in this way, more traditional tastes are directed to a recorded commentary from professional historians, Fiona Watson and Tony Pollard, both members of the project's Academic 
Advisory Panel, selected 'to ensure the new interpretation is strong and academically sound, based on acceptable and authoritative research and thinking'. ${ }^{8}$

Immersion techniques which seek to throw visitors into visceral experiences both 'realistic and historically accurate' are typical of the increasing trend towards affect in popular approaches to the past, and of an accompanying insistence upon recognised standards of accuracy. The real, in other words, however much it is actually a product of imaginative reconstruction and storytelling, is rhetorically both affective and intellectual; indeed the credentials bestowed by the latter act in vital validation of the former. 'The next generation is not the same as ours', say Bright White; 'technology has enabled a new way of life and new ways to learn'. ${ }^{9}$ Digital technologies have played a leading role in enabling these 'new ways to learn,' and their use at heritage sites has coincided with the rise of the 'affective turn' in the humanities, or, as La Caze and Lloyd have put it, the growth of ideas that have 'led us to rethink the frameworks of scholarship and research that have separated the mind from the body.' As critics of these re-enacted histories have often pointed out, the idea that we can experience events in other eras with any degree of affective verisimilitude assumes a 'collapsing of temporalities' and 'a privileging of experience over event or structure' which challenges all notion of the past as essentially different or unknowable. In so doing, it 'implies forms of historical continuity that are... potentially inaccurate', highly manipulable and somewhat at odds with the empirical authenticity conferred by academic expertise. Nevertheless, affective and empathic games have sparked the interest of the museum sector for the greater depths of engagement they bring to audiences traditionally 'hard to reach'. ${ }^{10}$

\section{Dialogic participation}

\section{i. ludic histories}

The third approach considered here is the most challenging. It concerns the use of mobile and digital technologies to change the nature of historical interpretation at sites of heritage from one in which visitors are encouraged to absorb 'factual' information to one in which they are encouraged to participate as interpreters. While the former requires a passive acceptance of the authoritative views of 'experts', sometimes without any display of evidence and often without debate, the latter offers visitors a glimpse of the historian's mental world and requires from them some evaluative thought. Apps that take visitors on a prescribed and guided walking tour of a site are rarely equipped to explore ideas of this kind, and the same is largely true of immersive tools like AR which focus on accurate simulation rather than alternative forms of interpretation. Yet what most sets historical analysis apart from other forms of enquiry in the arts and social sciences is the fragmentary nature of the evidence around which historians build interpretative frameworks, the material irretrievability of past events (and people), and the inevitability of supposition, argument and disagreement. Construction, in other words, is as necessary a concept to historians as reconstruction. Accepting that history is a practice in which knowledge is crafted from often incomplete evidence, and a practice characterised by uncertainty and informed speculation, challenges the authoritative basis on which explanation is conventionally built in the public sphere. Arguably, moreover, presenting the process of making history as a craft rather than the knitting together of a series of factual certainties offers the heritage industry an opportunity to engage audiences in genuinely interactive and dialogical ways.

These ideas have sometimes been addressed through play. A number of heritage sites have begun to borrow from the popularity (though with very different audiences) of computer games. Broadly, it has been proposed, 'video games that employ historical artefacts, characters, settings or events, either as a mode of storytelling or as a function of play, create a unique opportunity to affect 
historical understanding and improve its conventional interpretation' ${ }^{11}$ In educational environments, these principles have been successfully built upon for the teaching of history, and there is plenty of evidence for the positive role games can play in student learning. ${ }^{12}$ Historical themes have long been popular in computer games designed for entertainment rather than education. It is generally accepted by both designers and players that historically-set games limit the amount of historical analysis they include because too much information can over-complicate the game and make it unattractive. This has led historians to criticise what they see as an oversimplification of complex pasts and it is, perhaps, a measure of the influence exerted by some of these games that so much academic debate surrounds them. Parallel concerns have been aired from the point of view of heritage and its tangible and intangible associations with a site's 'sense of place.' Jess Malpas has argued that simulating an historic environment through the use of non-locative digital media assumes 'the idea that what matters to that place is not the actual location but rather the meaning that attaches to the location, a meaning that can, as it were, be "read from" the location and then recreated digitally, thereby recreating the place and the sense of place with it'. In this sense, the more we disassociate our understanding of the historic landscape from our immersive experience of the place itself, the more we restrict our appreciation of meaning. ${ }^{13}$ However much they may evoke 'the real' through detailed simulation then, the fact that they tend to take place remotely, in the home or the classroom, is dissassociative.

Most popular history simulation games are designed for entertainment rather than instruction and few have attracted more critical discussion than the Assassin's Creed series. ${ }^{14}$ In Syndicate, the most recent iteration of the game, players inhabit characters in an ambitiously realised simulation of London in 1868 and work to rouse the working class, 'driven to the Boroughs by the rich', against a syndicate of time-travelling Templars who seek to control the city. Although clearly an 'alternate' or counterfactual historical fantasy, the game nevertheless depends on researched contexts in order to appear convincing, so it contains an 'encyclopaedia' of buildings and characters, some of whom, confusingly, are 'real' (Darwin, Marx, Alexander Graham Bell) and others almost entirely fanciful (the pirate/assassin, Edward Kelway). Inaccuracies include the dating of London's first major outbreak of cholera to 1831 instead of 1832, and the heavy hand of Wikipedia can be detected in all of the encyclopaedia entries. Although, as Bob Whitaker has argued, to criticise what is essentially a game for the shortcomings of its historical content is rather to miss the point, ${ }^{15}$ some historians have nevertheless taken the makers to task. Alana Harris was invited to do so by The Guardian. Given that the game is set in the immediate aftermath of the Second Reform Act, Harris was disappointed by the absence of J. S. Mill as a character since consequent debates about the extension of the franchise to women might 'open out a gendered perspective on political discontent'. More critically, she felt the game's directive to liberate children from factory work (by removing their means of livelihood and sending them out into the street) betrays 'a very reductive understanding of what liberation for children might have meant in $1868^{\prime} .^{16}$ Syndicate is not the only popular computer game to be picked over for its historical inaccuracies. Games set in the ancient world, like Rome: Total War and Shadow of Rome have come under fire for an over-use of iconic buildings like the Colosseum, making them over-representative of a city, a time and a culture. Meanwhile, Roman military adventures featuring realistic portrayals of cavalry and equites are inexplicably augmented by fantasy units like Head-Hurlers and semi-fictional Gaulish Druids. After all, queries Dunstan Rowe, 'What are the Gauls without Druids?'17

The games industry's traditional defence against criticisms like these, that 'a game is just a game,' is somewhat flawed. Pure entertainment requires no historical accuracy at all, and yet, as Whitaker has shown, players of history games actually value scholarly authenticity very highly ${ }^{18}$ and game designers clearly go to some lengths to achieve it. However, there are more interesting debates to 
be had about game design, history and heritage if we move from a critique of graphic immersion to one of process. In The Oregon Trail, for example, a game which first appeared in the 1970s with the most rudimentary of graphics, players migrate their families to Oregon by wagon, making difficult decisions about resources against historically researched criteria on the way. As William Urrichio has said of it, 'the complexity of the game appears in historical simulation rather than in the representation of the historical moment'. ${ }^{19}$ Players learn something of the process of survival through a direct engagement with it. Adam Chapman too has tried to steer the critique away from a 'troubling' emphasis on historical accuracy towards 'an analytical framework that privileges analysis of form (i.e., how the particular audio-visual-ludic structures of the game operate to produce meaning and allow the player to playfully explore/configure discourse about the past) ${ }^{\prime 2}{ }^{20}$ If we can do this while broadening our understanding of gameplay to encompass 'real' social environments rather than their computer screen equivalents, we will go some way towards the theoretical rethinking advocated for heritage interpretation by Emma Waterton and Steve Watson. In an important review of heritage practice, and without referring to computer games as an alternative model, they "question the assumption that visitors are "recipients", largely passive, to whom communication is directed and for whom products are designed and encounters controlled'. They are equally sceptical about 'charges of inauthenticity, a shallow, trivial eclecticism and an overconcern with materiality, the dramatic and the visual. Processes of selection might thus be discerned that have criteria drawn more from the imperatives of effective marketing than genuine engagements with the past'. ${ }^{21}$

Educational institutions like the Smithsonian National Museum of American History have shown what can be done if we transfer some of these ideas about process from computer games like Oregon Trail to apps based on actual collections rather than imaginative stories, designed as i-pad downloads for school and college use. Ripped Apart: A Civil War Mystery allows users to take on the role of a museum intern, tasked with working through the Museum's Civil War photographic carte de visite collection to research what it reveals about the impact of war on ordinary individuals from either side. Biographies must be pieced together with help from a virtual curator, manuscripts deciphered and problems solved so that the spirits of some of the sitters can be freed from the boxes in which they have been confined in the Smithsonian's basement (the 'game' element). On completion, when their interest has been stimulated, users obtain access to a web database of the entire collection and extensive biographical and provenance notes for each photograph. The app prioritises evidence based decision-making as well as the absorption of 'information' because, as curator Carrie Kotcho puts it, 'until you actually do history, you're really not learning what history's all about. ${ }^{22}$

These levels of engagement with processes of historical construction are only very occasionally replicated in apps for locative media. Typical of the Smithsonian's interactive apps for mobile is the far more conventional History Hero, in which layers inhabit fictitious characters to explore American and European historic buildings in real time, tasked with finding 'important' heritage assets within, answering a few simple questions about them, and scoring points, thereby safeguarding them from an alien species whose ambition is to erase 'our' common sense of history by stealing 'our' heritage. In London, however, our heritage is only to be found in the city's best known cultural institutions its major art museums, the British Museum and the Tower of London - where the only artifacts to be safeguarded are fine paintings, palatial remains and the Crown Jewels. ${ }^{23}$ There are stronger models than this; the collaboratively produced Frequency 1550, for instance, uses mobile to enable teams of players to explore the medieval streetscape of Amsterdam, problem-solving as they go and learning about historical urban space in situ. Another project, Geist, guides visitors around historic Heidelberg with the aid of AR reconstructions delivered to their phones, 'using history to allow the 
viewer to experience how it felt to be in that city during the thirty years war in the seventeenth century'. Yet another, Who Killed Hanne Holmgaard? engages visitors to Aalborg as it was under Nazi occupation in 1944. Players adopt the characters of real detectives from the period whose experience in policing the city is recorded in a published memoir and this becomes the context for a quest to solve the (fictitious) murder of a Danish nun. ${ }^{24} \mathrm{My}$ argument here however, is that genuine engagements with the past, in place, can also be as much about the process of 'doing history' and problematizing the evidence as either being informed about it, or simply trying to empathise.

\section{ii. Ludic histories and locative mobile}

If gaming principles can be wrested from remote screens and applied in pervasive and locative form, their potential for engaging visitors to sites of heritage with novel kinds of interpretation is obvious enough, and should have the capacity to move us beyond the concerns about displacement voiced by Malpas. But how useful has it turned out to be in practice? A common characteristic of historically-set computer games is a preponderance of sweeping narratives about warfare, trade, statecraft and nation-building. ${ }^{25}$ Indeed, Jerome de Groot's critical appraisal of them in his recently revised and updated Consuming History, is concerned with these themes to the exclusion of all others. An 'underlying ludicness', he concludes, 'associated with mediated discourses of knowing, throws history into a complex set of interactions', but his assessment of the phenomena remains ambivalent. Historical knowledge is both concrete - the "right" answer - and something that can be played with, manipulated' ${ }^{26}$ Most computer games, as Kevin Schut has pointed out, with their privileging of aggressive and acquisitive behaviours, have preserved distinctly masculine approaches to history that are quite out of step with the formulations of the modern academy. The tendency of older mainstream histories to 'write marginal social groups out of our cultural historical consciousness' has been under revision by historians since at least the 1960s, but 'digital games tend to reinscribe it'. ${ }^{27}$ Fears like these were enough, a few years earlier, to provoke Eric Champion's remark that, 'using typical game interaction for virtual heritage could be encouraging violent and destructive behaviour towards culturally significant artefacts'.$^{28}$ On the face of it, the grand, epic and often bloody concerns of computer games set themselves at a considerable distance from those of the average British heritage attraction, the ubiquitous country house, the landscape garden and the royal palace. Moreover, industry statistics confirm an expectation amongst a majority of smartphone and tablet gamers of either gender that downloadable apps will give them opportunities to fight. ${ }^{29}$

Yet, locative app designers have certainly begun to think in computer-gaming terms, and at the most basic level, to offer encouragement through incentives and rewards. On the Audio-Tours 'Welcome To...' platform, for example, 'when visitors are at one of the historic sites they can check-in to receive a badge, and if they're a keen explorer they'll earn group badges for visiting themed sets of buildings'. Some more bespoke projects have gone further. In 2012, in a bid to persuade more visitors to take a circuit of the city walls, Chester West and Cheshire Council's 'Chester Renaissance' initiative commissioned a specialised phone app called 'The Walls Quest'. This venture was financed through partnership with the European Portico project which brought archaeologists, artists, designers and engineers to Cologne, Ghent and Utrecht as well as Chester, 'to help cities across Europe to protect and use their archaeological heritage for economic benefit'. The design brief emphasised a conscious departure from conventional audio guides: 'Instead of a usual interactive tour guide we looked to the world of video gaming to guide the project. More than 31 million people in the UK play video games and the average young person in the UK will now spend 10,000 hours gaming before the age of twenty-one. The video games industry definitely know something about motivating people to take part in an experience'. Advertising for the resulting app emphasised its difference. Blending quizzes with visual reconstructions of key events from a range of periods in the 
city's history and a series of collecting games, 'Walls Quest is more than just a guide - it's an adventure. You'll need to be observant, use your imagination and be ready to take part in the Quest Challenges. You'll be rewarded with Quest Points, be able to unlock special Guild Shields and the best Questers will win special bonus games to play... ${ }^{30}$

This is gaming in the service of widening participation, but not necessarily in the service of historical understanding. There are decisions to be made in Walls Quest, but they cannot change the nature of a player's experience, only help him or her accumulate virtual points, badges and shields. To the extent that nothing challenging is required of the player, the visitor experience remains a passive one, despite the piling up of activities, and the historical narratives introduced adopt familiar perspectives 'from above', denying dissonance, debate or alternative perspectives. These are common traits, as any survey of downloadable heritage-themed apps with playful features will quickly confirm, whether marketed by small independent sites or national educational institutions.

Yet games have the potential to do very much more than this, as Greg Costikyan's influential definition of what makes a game reminds us:

'Stories are inherently linear. However much characters may agonise over the decisions they make, they make them the same way every time we re-read the story, and the outcome is always the same... Games are inherently non-linear. They depend on decision making. Decisions have to pose real, plausible alternatives or they aren't real decisions. It must be entirely reasonable for a player to make a decision one way in one game and a different way in the next. To the degree that you make a game more like a story-more linear, fewer real options - you make it less like a game' ${ }^{31}$

In what Anja Sisarica and Neil Maiden have termed 'Creative Game-Based Learning' (CGBL), gaming principles have more recently been theoretically adapted for real-world problem solving and to 'rediscover cultural heritage'. The CGBL model prioritises two basic activities,

'exercising judgement during game play, then reflecting to learn after game play. Game play takes place in an environment that encourages and supports humour, idea support, trust and safety, persistence, freedom and playfulness. The game's content and environment are designed to encourage players to undertake certain types of creative thinking throughout the play process'. ${ }^{32}$

A limited number of makers for outdoor heritage sites have got the message and are using games in mobile applications that subvert the principle of didactic, information-heavy interpretation very successfully. Jewish Time Jump (discussed in detail elsewhere in this issue by Owen Gotlieb) is one very effective example; Up River is another. This is an app-based locative game, played in and around the estuary of the St Louis river, in which players follow clues, read maps and meet virtual characters from the estuary's history while following a real-time quest to find wild rice for cooking a local meal. Players will not encounter warfare or collect superfluous badges, but they may meet 'historical figures, such as Henry Schoolcraft, a 19th century geographer and ethnologist, who shares original journal entries describing the harbour area in the early 1800 s, long before it was altered by large scale European settlement and industrialization'. In effect, Up River is environmental history from below. It might have worked as an armchair console game but the advantages to experiential learning of using the actual environment, with its natural soundscape, local smells, changeable weather and passing people, as a backdrop are obvious. ${ }^{33}$ 
There is more to challenging the 'authorised heritage discourse ${ }^{34}$ in mobile interpretation practice than shifting content to reflect histories of place that are not dominated by elite narratives. As I have suggested here, history from below embraces not only an alternative approach to content but a dialogical approach to methodology. In essence, this is what Jeff Malpas was expecting of new media in 2008; 'new ways to enter into existing places - often by drawing upon neglected sensory modalities or by bringing to the fore aspects of the place that may otherwise go unnoticed or be difficult to access - that look to enable new modes of engagement between users or new forms of collective activity'. ${ }^{35}$

Two attempts to engage public audiences with issues of historical social disorder are worth considering in this context. In 1831, public anger at the rejection of Lord Grey's Reform Bill by the House of Lords sparked serious rioting in a number of provincial towns, including Bristol and Nottingham, a great many deaths at the hands of the military and a series of public hangings. As one might expect, the heritage industry in both towns has struggled over the public commemoration and interpretation of these destructive and politically divisive events. In 2004, writers, Liz Crowe and Ralph Hoyte worked with Hewlett Packard labs to produce 1831 Riot!, an interactive soundscape for Bristol's Queen Square (the riot epicentre) in which audiences navigated their own pathways through dramatically reconstructed scenes with the use of headphones. Dubbed 'the world's first audio-play for located media in an intelligent environment', the project's immersive and non-linear framework was developed specifically to address the confused and multi-vocal nature of the events it portrayed. 1831 Riot! was innovative in that it imposed no authoritative third-party commentary; on the contrary, it provided a space in which the evaluation and ordering of voices, perspectives and events was a function of audience agency. Users were not addressed personally by historical characters however, or directed where to go. Ten years on, Nottingham Castle Museum's Riot 1831 (2014), handsomely funded by the Digital R\&D Fund for the Arts, also made use of first hand eyewitness testimony, but exchanged locative audio with AR via a downloadable phone app. This made it easier to stage the project in the museum galleries and retained the objective of user agency by offering audiences conflicting accounts to unravel, but in the process became somewhat reductive. When faced with a scene in which rioters set fire to the Castle, for example, audiences were asked to signal their approval or non-approval by deciding whether or not to throw more furniture onto the blaze. Advances in technology may not always lead to advanced methodology. ${ }^{36}$

\section{Ghosts in the Garden: an Adventure Heritage manifesto}

If we are to reject the authoritative single voice of the guidebook in favour of new forms of evidence- based interpretation, can we agree a set of broad principles under which to carry the argument forward? In 2012, REACT, the AHRC's South Western creative economy hub, funded a research project in Bath that addressed this question directly. Ghosts in the Garden was conceived as a partnership between the Holburne Museum, Splash \& Ripple (a Bristol-based experience design company) and myself (an academic historian from the University of the West of England, Bristol). ${ }^{37}$ Although now a museum, the Holburne was originally built in 1795 as the grand entrance to Bath's newest and most fashionably exclusive pleasure ground, Sydney Gardens. The gardens, designed as Bath's answer to Vauxhall Gardens in London were, in their Georgian heyday, a monument to light, colour, food, drink, and crowded public entertainments. Amongst their winding walks and shady groves, they boasted a series of 'medicinal' swings, a maze, a sham ruined castle, a hermit's cottage, a mechanical cascade and, by 1824, a Cosmorama. Today however, Sydney Gardens is a municipal park to the rear of the museum and virtually nothing remains of the original design. The project's brief then, was to create an innovative GPS-enabled mobile interpretation tool capable of conveying 
a sense of what was formerly there. The project's approach to place-making would be participatory and non-didactic.

A number of self-imposed qualifications followed. As an intentionally designed elite space in Britain's premier Georgian spa town, the Gardens prompt very traditional interpretation narratives. A large cast of bankable Regency celebrities passed through them, most notably Jane Austen who wrote about her own experience there in letters to her sister. Jane is an enduringly popular heritage icon in Bath; indeed an entire visitor centre is devoted to her in Gay Street, yet the thousands of ordinary visitors who entered the Gardens for daily exercise or on Gala evenings were not drawn from a restricted social elite. The first qualification therefore, was that the gardens would be approached 'from below' and that neither Jane nor any of her ubiquitous heritage friends would be called upon to make an appearance. The museum had some understandable initial misgivings. It was agreed however, not only that associating the Gardens with a broader social constituency would be more 'authentic', but that since doing so would require new research, a number of previously overlooked historical characters, perspectives and narratives might emerge, conferring unique status on the project amongst the city's Georgian attractions. New research would, in turn, require historical scholarship and the active participation of a professional social historian. Since garden history is rarely approached academically from a dissonant perspective, the project might even be regarded as an innovative platform for 'publishing' historical research. Here the project would explore Dawn Spring's assertion that digital games should be regarded as a viable tool in the making of new scholarly histories and a form of publication in their own right. ${ }^{38}$

A second qualification was a rejection of screen-based delivery. To prioritise locative and affective engagement with period and place, an effort was made to minimise overt technological presence. While it was recognised that innovations in augmented and virtual reality software, together with the continuing spread of personal smartphones, has made screen-based interaction with downloadable apps ubiquitous across the heritage sector, Ghosts in the Garden was designed to complement the material reality of space and subjective immersion in place, so tablets and phones would not feature. Rather than attempt visual reconstructions of vanished buildings and past events, the project would engage audiences through audio alone, provoking imaginative reconstruction in the mind of the user. A subsidiary decision was made to dispense with headphones since it was felt that isolation, either from other visitors or from the actual sounds of the environment might be equally obstructive to an understanding of place and to social interaction. The most critical qualification concerned agency. Audiences would be required to interact with content by listening to evidence in dramatic re-enactment, making informed decisions and exploring the space as a consequence. There would be no authoritative commentary, but contextual learning about the nature of Georgian pleasure gardens would be a natural outcome of engaging with researched content.

Archival research produced a cast of historical characters from the 1820s, an important period in the Gardens' history, in which the spread of disposable income amongst lower middle class and working class audiences broadened the social mix of paying customers and created tensions around the Gardens' reputation as a haven for peace and politeness. A cast list of ropedancers, firework impressarios, vagrants, police constables and pick pockets emerged from the archives to populate a new garden history from below. For this, original research was vital. Locating county quarter session depositions recording the arrest and questioning of Sydney Gardens pick pockets for example, made it possible to research the criminal careers of several previously unknown petty thieves, to consider polite social space from an unusual perspective, and build one of them, James Wiltshire, into the project as a fully developed character. Other characters retrieved from contemporary sources 
included an Irish beggar nicknamed Dancing Jerry, well-known at Bath in the 1820s but forgotten today, and a local comic performer of doubtful talent, James Woulds.

Most importantly, research revealed that William Bridle, the Garden's proprietor from 1824-30, was the man better known to historians of crime and radicalism as the former governor of Ilchester Gaol, who had clashed with Henry 'Orator' Hunt while Hunt had been Bridle's prisoner after Peterloo. In 1824, after a bitter legal battle and a series of allegations of corruption and prisoner mistreatment, pursued by Hunt and strongly denied by Bridle, the governor was removed from his job, his personal reputation in tatters. Within months, he quietly began to reinvent himself at Bath as a manager of leisure and entertainment rather than punishment. Although much has been written about the Ilchester allegations, from Hunt's perspective, Bridle's later life and the impact on public opinion at Bath of his surprising appointment at Sydney Gardens was previously unknown. ${ }^{39}$ These discoveries proved vital to narrative development for Ghosts in the Garden and Bridle's appearance as a character in the project may be regarded as a form of scholarly publication. It led, in turn, to publication in more conventional textual form, but it would not have been possible without the research requirements of the digital project. ${ }^{40}$ In building the project around characters and situations like these, the intention was not to supersede more conventional histories of pleasure gardens but to suggest to visitors that a place has many histories and that our understanding of it is influenced by the narratives we choose to represent it.

Essential to the argument was a proposition that quotidian stories and characters from the historical record can be as engaging to audiences as stories about celebrities and social elites because they reflect the life experiences of modern garden visitors. Narratives were essentially linear but variable. Audience evaluation of Hoyte and Crowe's 1831 Riot! project had confirmed that users enjoyed 'the simple interaction model of walking to trigger sounds without the need to interact with a physical user interface,' but 'the absence of any temporal sequencing was problematic and confusing.' Ghosts in the Garden developed a walk-to-unlock model along the lines pioneered in 1831 Riot! but rather than leave visitors to randomly stitch the narrative together, it offered them a number of logical alternatives. ${ }^{41}$ Audiences moved around the gardens according to choices offered to them by virtual characters encountered at each stopping point. This was engineered by the addition of a 'choose your own adventure' (CYOA) game mechanic, which requiring decision-making at each location as content was absorbed and evaluated. Eric Champion's objection, in 2008, that games were 'strategic or physical challenges, not thinking tools', offering 'too few opportunities for reflective thinking', would therefore be directly addressed. ${ }^{42}$

The multi-option structural framework of CYOA ensured not only that audiences effectively curated their own visits in response to content, but that, since narratives and outcomes were dependent on decisions taken, repeat visits and alternative interpretations were encouraged. Importantly then, any objections that intruding a game, by Costikyan's definition, into historical interpretation creates fictions which invalidate educational impact may be countered by arguing that process and methodology are as important to an understanding of history as the 'correct' course of events, and that this is a process privileged by CYOA. Finally and crucially, Ghosts in the Garden called for a delivery system that was not reliant on visitors downloading an app or using a smartphone or screen. Here a solution was sought in the creation of a Georgian 'Time Radio,' an imaginative prop in which a smartphone and speaker could be concealed, but of sufficiently intriguing design to ensure it became an object of playful desire. Moreover, it would require no acquaintance with technology to operate. Visitors were instructed simply to walk into the Gardens with it and listen. Triggered by GPS, historical characters would 'sense' their presence, address them, and pull them directly into the narrative. Rather than announce their use for digital interpretation or 'information', Holburne 
museum staff were tasked with asking visitors to take a Time Radio as volunteers testing recently discovered mechanical artefacts with mysterious but unproven properties. Visitors were very aware, therefore, that they were beg asked to take part in something imaginative and playful.

The Ghosts in the Garden approach to heritage interpretation adapts some elements of first-person computer games like Call of Duty and Medal of Honour; most notably in its attempt to subjectively immerse visitors in a past reality in which they are called upon to make decisions that impact upon outcomes. As Andrew Salvati and Jonathan Bullinger have pointed out, 'selective authenticities' in which 'feel' and 'experience' matter more than 'factual fidelity' can lead to tensions in attempts to simulate major conflicts, the actual outcomes of which are very well known. But, unlike Call of Duty and its ilk, the key objective behind Ghosts in the Garden was to use immersion to convey an everyday social experience that has been either completely lost to most modern audiences or popularly interpreted from a very limited (elite) social perspective. Two narrative threads were dramatized by script writers and digitally voiced by actors. In the first, Bridle's conflicted back story as a former prison governor is slowly revealed and visitors must choose between helping two vengeful labourers to sabotage his Gala fireworks or helping him to uncover the plot and foil them. In the second, a young ropedancer on an allegedly exploitative contract tries to elope with her lover by commandeering a balloon brought into the gardens by the popular aeronaut, James Graham. Visitors choose either to assist with her escape or prevent it. In each scenario, contextual historical detail is absorbed while the character and claims of historical figures are tested. While it was important to the project that its narratives were based on researched archival evidence, the stories did not carry the consequential gravitas of those used in World War battle games and there was little danger of any factual inaccuracies compromising public understanding of its objectives. ${ }^{43}$

In audience evaluation, visitors were asked what, if anything, they had learned about Georgian pleasure gardens. $73 \%$ agreed that it had been 'in some way educational' and, as expected, given that there was no prior directive given to learn, answers were varied: 'music of different kinds was played in different parts of the park'; 'we learned about the Cosmorama'; 'they needed police to stop pick pockets'; and 'they organised really expensive and massive firework displays', are indicative examples. These gleanings were not essential components of the narratives visitors had been following, but were picked up contextually from conversations between characters. Importantly then, a degree of learning had taken place without visitors knowingly signing up to 'education'. 19\% of visitors asked, unprompted, whether what they had just heard was 'true' or not. Given an awareness that the choices they had made in the gardens must have materially affected the course of the narrative, they were clearly not asking whether the story they had heard was 'correct' but whether the overall experience was historically accurate. This is not a concern visitors would be expected to have at sites of heritage where the presentation of information and the manner of its interpretation appears unquestionable, but it is perhaps understandable in a situation where visitors have been interacting with scripted characters through a Time Radio. Whether they asked this question or not however, at the conclusion of each visit, players were given a Character Booklet containing short biographies of all the individuals encountered, outlines of the events and scenarios on which the scripts were based, and notes on the archival sources from which they had been drawn. Since it was important to the project that it enabled an understanding of historical processes and methodology, revealing sources and confirming a relationship between empirical research and imaginative fiction was integral.

As a funded research and development project, Ghosts in the Garden was not designed for permanent installation at Sydney Gardens. The elaborate and bespoke Time Radios were expensive 
to manufacture and the Holburne Museum did not have the budget to adopt the project after its initial testing. However, the basic tenets of the design brief were developed by Splash and Ripple into an 'Adventure Heritage Manifesto' and tested commercially through an installation for the National Trust who commissioned a medieval variant in 2013 (A Knight's Peril, using Echo Horns instead of Time Radios) at Bodiam Castle in Sussex. Ultimately, Ghosts in the Garden is best understood as a set of principles to guide future interpretation. As Luigina Ciolfi has argued, the current affective, individualistic and interactive trend in planning the visitor experience at heritage sites closely complements parallel developments in human-centred computing and the two tend to advance in tandem. Ciolfi's practice-based research, which focusses on 'experiences of place, embodiment and materiality' at outdoor sites of heritage, has explored the potential for enhanced mobile intervention at two contrasting sites; a purpose-built attraction, Bunratty Folk Park in Ireland, and a municipal site that has unintentionally become one, the Sheffield General Cemetery. Nonintrusive prototypes were produced for each site, ranging from an interactive digital book to a set of binoculars through which to view AR slides, each driven by notions of playfulness and concealment. The binoculars, for example, like Splash and Ripple's Time Radios, were designed to hide the technology that actually delivered the experience. Ciolfi's research is unique in its attention to the affective relationship between technology, place and outdoor heritage but further evaluative work is called for. ${ }^{44}$

As argued above, affective interpretation that privileges emotion, personal response and feeling as essential components of heritage can be a source of conflict amongst audiences for whom dispassionate factual rigour is essential to the understanding of history. For these audiences indeed, the very notion of playing games with historical evidence may be anathema. Ghosts in the Garden was an attempt to square the circle by presenting the process of narrative construction in history as simultaneously rigorous and creative and to use game as a tool for building understanding. It was rooted in place and, given a landscape with no tangible remaining reference points, intimately involved in place-making. Future research might profitably continue this investigation, because the potential for using mobile locative technologies for unlocking not only the history of a place but the process by which we construct and question that history, has been overlooked for too long. 
${ }^{1}$ The research for this essay was made possible by an Alumni Award from REACT, the South West creative economy hub established from 2012-16 by the Arts and Humanities Research Council. I am extremely grateful to REACT and to the Bristol experience design company, Splash \& Ripple, for being a constant source of stimulation over the last four years.

${ }^{2}$ A phenomenon effectively critiqued by Bas van Heur as in institutionally conditioned 'digital imperative'; Bas van Heur, 'From analogue to digital and back again: institutional dynamics of heritage innovation', International Journal of Heritage Studies, 16, 6 (2010).

${ }^{3}$ L. J. King, C. Gardner McCune, P. Vargas and Y. Jimenez, 'Rediscovering and recreating African-American historical accounts through mobile apps: the role of mobile technology in history education', Journal of Social Studies Research, 28 (2014).

${ }^{4}$ Much of the running has been made in museums rather than at outdoor sites of heritage, but in recognising the potential of smart mobile devices to dissolve the museum's material boundaries and extend the visitor experience to the external environment, museum applications have been influential on wider heritage practice. See for instance the useful survey in L. Talon and K. Walker (eds.), Digital Technologies and the Museum Experience: Handheld Guides and Other Media (Plymouth: Altamira Press, 2008). For technical focus see A. Brown, G. Saeed and M Knight, 'Finding your way around heritage sites: the delivery of digital information to mobile devices', International Journal of Architectural Computing, 7, 1 (2010). For a broad but fairly uncritical overview of serious games for heritage, see M. Mortrava et al., 'Learning cultural heritage by serious games,' Journal of Cultural Heritage, 15 (2014).

${ }^{5}$ For Audio Tours see http://www.audiotrails.co.uk/what-we-do/heritage-apps/; for Calvium

${ }^{6}$ http://www.ats-heritage.co.uk/projects/

7 http://www.treasuretrails.co.uk/lancashire/location-based-apps-mpa.

8 R D. Crammond, 'The objectives of the National Trust for Scotland's Visitor Centre at Culloden Battlefield, and the educational effectiveness, for visitors, of its History content' (2012),

(http://www.nts.org.uk/culloden/Downloads/CullodenDissertation.pdf); 'Bringing the Battle of Bannockburn to life for the $21^{\text {st }}$ century' (2012); 'Prepare for Battle at the new Visitor Centre (2014); 'Meet the Experts'

(2014); 'Bannockburn victory at UK Heritage Awards' (2015)

(http://www.battleofbannockburn.com/updates/news/).

${ }^{9}$ See Bright White's 'Philosophy', (http://www.brightwhiteltd.co.uk/\#articles)

${ }^{10}$ Marguerite La Caze and Henry Martyn Lloyd, 'Editor's Introduction: Philosophy and the Affective Turn', Parrhesia, 13 (2011), p.6; Vanessa Agnew, 'History's affective turn: Historical re-enactment and its work in the present', Rethinking History, 11, 3 (2007), pp.299-312; Jenny Kidd, 'Gaming for affect: museum online games and the embrace of empathy', Journal of Curatorial Studies, 4, 3 (2015).

${ }^{11}$ Rolfe Daus Peterson, Andrew Justin Miller and Sean Joseph Fedorko, 'The same river twice: exploring historical representation and the value of simulation in the Total War, Civilisation and Patrician franchises', in Matthew Wilhelm Kapell and Andrew B. R Elliott (eds.), Playing With the Past: Digital Games and the Simulation of History (Bloomsbury: London \& New York, 2013), p.34.

${ }^{12}$ Shannon Kennedy-Clark and Kate Thompson, 'What do students learn when collaboratively using a computer game in the study of historical disease epidemics, and why?', Games and Culture, 6, 6 (2011). See also Jeremiah McCall, Gaming the Past: Using Video Games to Teach Secondary History (Routledge, New York and London, 2011).

${ }^{13}$ Jeff Malpas, 'New media, cultural heritage and the sense of place: mapping the conceptual ground', International Journal of Heritage Studies, 14, 3 (2008), p.204.

${ }^{14}$ See for example, Douglas N. Dow, 'Historical veneers: anachronism, simulation and art history in Assassin's Creed II', Kapell and Elliott (eds.), Playing With the Past, where the impact of architectural inaccuracies in the game's simulation of fifteenth century Florence upon a player's ability to distinguish reality from its representation is discussed.

${ }^{15}$ Robert Whitaker, 'Backward Compatible: Gamers as a Public History Audience', Perspectives on History (American Historical Association, Jan 2016) (http://historians.org/publications-and-directories/perspectiveson-history/january-2016/backward-compatible-gamers-as-a-public-history-audience). Whitaker is an academic historian with a parallel interest computer games and the instigator of History Respawned, a Youtube Channel in which he discusses the historical content of various games over real-time 'let's play' walk-throughs. See https://www.youtube.com/watch?v=ibwhQN3wNL4 for Assassin's Creed: Syndicate. 
${ }^{16}$ Holly Neilsen, 'Reductive, Superficial, Beautiful - A Historians View of Assassin's Creed: Syndicate', The Guardian, 9 September 2015 (http://www.theguardian.com/technology/2015/dec/09/assassins-creedsyndicate-historian-ubisoft). Neilsen's article provoked 374 public comments, debating the importance of historical accuracy in computer games.

${ }^{17}$ Dunstan Lowe: 'Playing with Antiquity: Videogame receptions of the classical world', in Lowe, D. and Shahabudin, K, (eds), Classics For All: Reworking Antiquity in Mass Cultural Media. (Newcastle Upon Tyne: Cambridge Scholars Press, 2009) pp.76, 86.

${ }^{18}$ Robert Whitaker, 'Backward Compatible'.

${ }^{19}$ William Urrichio, 'Simulation, history and computer games', in J. Raessens and G. Goldstein, The Handbook of Computer Games (MIT, 2005), p.331.

${ }^{20}$ Adam Chapman, 'Privileging Form over Content: Analysing Historical Video Games', Journal of Digital Humanities, 1, 2 (2012) http://journalofdigitalhumanities.org/1-2/privileging-form-over-content-by-adamchapman/

${ }^{21}$ Emma Waterton and Steve Watson, 'Framing Theory: Towards a Critical Imagination in Heritage Studies', International Journal of Heritage Studies, 19, 6 (2013), p.549.

${ }^{22}$ See archived webinar for this app at http://americanhistory.si.edu/ripped-apart

${ }^{23}$ For a brief but uncritical discussion of these issues from industry insiders, see N. Proctor (ed.), Mobile Apps for Museums: The AAM guide to planning and strategy (Washington: AAM Press, 2011).

${ }^{24}$ Discussions of these applications will be found in N. Avouris and N. Yiannoutsou, 'A review of mobile location-based games for learning across physical and virtual spaces', Journal of Universal Computer Science, 18 (2012) and J. Paay and J. Kjeldskov, 'Location-based storytelling in the urban environment', OZCHI (2008).

${ }^{25}$ This preponderance is reflected in the weight given to war games in critical scholarship. The 23 essays in Kapell and Elliott's Playing with the Past, the key reader on history and computer gaming, are overwhelmingly concerned with the historical representation and simulation of war and diplomacy, and not at all with everyday life. See Matthew Wilhelm Kapell and Andrew B. R Elliott (eds.), Playing With the Past: Digital Games and the Simulation of History (Bloomsbury: London \& New York, 2013).

${ }^{26}$ Jerome de Groot, Consuming History: Historians and heritage in contemporary popular culture (Routledge, $2^{\text {nd }}$ edition, 2016), p.162.

${ }^{27}$ Kevin Schut, 'Strategic simulations and our past: The bias of computer games in the presentation of history', Games and Culture, 2, 3 (2007), p.220-1.

${ }^{28}$ Eric Malcolm Champion, 'Otherness of place: game placed interaction and learning in vrtual heritage projects', International Journal of Heritage Studies, 14, 3 (2008), p. 216.

${ }^{29}$ As reported, for example, by bloggers on the games industry's leading web resource, Gamasutra in 2016: Mantin Lu, 'RPG and action games will dominate the gaming market in 2016', http://www.gamasutra.com/blogs/MantinLu/

20160226/266701/RPG_and_Action_Games Will_Dominate the Mobile_Gaming Market in 2016 Report.p hp . 55\% of app game downloads are personal combat-focussed.

${ }^{30}$ http://www.explorethewalls.com/

${ }^{31}$ Greg Costikyan, 'I have no words and I must design: towards a critical vocabulary for games', K. Salen and E. Zimmerman (eds.), The Game Design Reader: A Rules of Play Anthology (Cambridge, Mass: 2006), p.194.

${ }^{32}$ Anja Sisarica and Neil Maiden, 'An emerging model of creative game-based learning', Conference Proceedngs, $4^{\text {th }}$ SGDA International Conference, Trondheim, Norway 2013 (Heidelberg: Springer, 2013), P.258.

${ }^{33}$ Mark Wagler and Jim Matthews, 'Up River: Place, Ethnography and Design in the St Louis River Estuary' (Carnegie Mellon University: ETC Press, 2012) (http://press.etc.cmu.edu/content/river-place-ethnographyand-design-st-louis-river-estuary. For two museum-based applications that work in similar ways see Seann Dikkers, 'History in Our Hand: Mobile Media in Museum Adventures' (Carnegie Mellon University: ETC Press, 2012) (http: / / press.etc.cmu.edu/content/history-our-hands-mobile-media-museum-adventures ) and Play the Past's 'Then Now Wow' learning project for schools at the Minnesota History Centre: https: //www.youtube.com/watch?v=9AgE5w7Pril 
${ }^{34}$ The phrase is Laurajane Smith's. See Uses of Heritage (Routledge, 2006), pp.29-34.

${ }^{35}$ Malpas, 'new media', p.207.

${ }^{36}$ For the Bristol project see http://www.ralphhoyte.com/\#/1831-riot/4586745624 ; for Nottingham see http://www.nottinghamcastle.org.uk/explore/riot-1831-gallery and the R\&D Fund report pages at http://artsdigitalrnd.org.uk/projects/nottingham-city-museums-galleries/

${ }^{37}$ Luigina Ciolfi, 'Embodiment and Place Experience in Heritage Technology Design', Museum Media Pt 3, Design and Curating in the Media Age, The International Handbooks of Museum Studies (2015); Anja Sisarica and Neil Maiden, 'An emerging model of creative game-based learning' Serious Games Development and Applications, Lecture Notes in Computer Science, Vol 8101, pp.254-9; https://vimeo.com/60239838.

${ }^{38}$ Dawn Spring, 'Gaming history: computer and video games as historical scholarship', Rethinking History, 19, 2 (2015).

39 John Belchem, 'Orator' Hunt: Henry Hunt and English Woking Class Radicalism (Oxford, 1985); Margot C. Finn, 'Henry Hunt's "Peep into a Prison": the Radical Discontinuities of Imprisonment for Debt in G. Burgess and M. Festenstein (eds.), English Radicalism, 1550-1850 (Cambridge, 2007).

${ }^{40}$ Steve Poole, 'Pleasure... and shame: reputation and respectability at Sydney Gardens, Bath, 1820-1830, Bath History (forthcoming, 2016).

${ }^{41}$ M. Blyth, J. Reid, P. Wright and E. Geelhoed, 'Interdisciplinary criticism: analysing the experience of Riot! a location sensitive digital narrative', Behaviour and Information Technology, 25, 2 (2006), p.131-2.

${ }^{42}$ Champion, 'Otherness of place', p.215.

${ }^{43}$ Andrew J. Savati and Jonathan M. Bullinger, 'Selective authenticity and the playable past', in Kapell and Elliott (eds.), Playing With the Past, pp.162-3.

${ }^{44}$ Luigina Ciolfi, 'Embodiment and Place Experience in Heritage Technology Design', in Michelle Henning (ed.), The International Handbooks of Museum Studies: Museum Media (John Wiley, 2015). 